\title{
Pembuatan Tepung Wortel (Daucus carota L) Ditinjau dari Varietas Wortel dan Konsentrasi Na-Metabisulfit terhadap Kandungan Total Karoten
}

\author{
Siti M. Sholihah \\ Program Studi Agroteknologi Fakultas Pertanian Universitas Respati Indonesia Jakarta \\ Email: nur.sholihah18@gmail.com
}

\begin{abstract}
ABSTRAK
Wortel (Daucus carota L) merupakan bahan makanan yang mengandung karoten (pro vitamin A), thiamin, riboflavin dan tinggi kandungan gulanya. Sebagian besar wortel dikonsumsi dalam bentuk segar, diolah untuk sayur, dan ada juga yang dibuat juice. Penanganan wortel yang tepat untuk memperpanjang daya simpan, karena mudah sekali rusak adalah dengan cara dikeringkan dan diolah menjadi tepung wortel. Tepung wortel dapat digunakan sebagai campuran makanan bayi, campuran saos, dan sebagai bahan pewarna alami (colouring agent) untuk produk makanan khusus, seperti keju, ice cream, margarin, roti dan lain-lain. Tujuan penelitian ini adalah untuk mengetahui pengaruh varietas wortel dan konsentrasi Na-metabisulfit terhadap kandungan total karoten tepung wortel. Penelitian ini menggunakan Rancangan Acak Kelompok secara factorial dengan 2 faktor dan 3 kali ulangan. Faktor 1, yaitu Varietas wortel (W) : varietas Arnas (W1) dan varietasTosari (W2), sedangkan faktor ke 2, yaitu Konsentrasi Na-metabisulfit (S) : 250 ppm (S1), 500 ppm (S2), dan $750 \mathrm{ppm}$ (S3). Hasil penelitian menunjukkan mutu tepung wortel yang baik diperoleh dari kombinasi perlakuan varietas Tosari dengan konsentrasi Na-metabisulfit 500 ppm. Tepung wortel yang dihasilkan mempunyai penurunan total karoten sebesar 5,46\%; kadar air 2,84\%; Aw 0,36; rendemen 6,56\%; residu $\mathrm{SO}_{2} 54,4 \mathrm{ppm}$; tingkat kesukaan warna dan bau sebesar 8,07 dan 5,87 .
\end{abstract}

Kata Kunci: tepung wortel, arnas, tosari, total karoten

\begin{abstract}
Carrot (Daucus carota L) is a food ingredient that contains carotene (pro vitamin A), thiamin, riboflavin and high sugar content. Most carrots are consumed in fresh form, processed for vegetables, and some are made into juice. Proper handling of carrots to extend shelf life, because they are easily damaged is by drying and processing into carrot flour. Carrot flour can be used as a mixture of baby food, a mixture of sauces, and as a natural coloring agent for special food products, such as cheese, ice cream, margarine, bread and others. The purpose of this study was to determine the effect of carrot variety and Na-metabisulfite concentration on the total carotene content of carrot flour. This study used a factorial randomized block design with 2 factors and 3 replications. Factor 1 is carrot variety (W): Arnas variety (W1) and Tosari variety (W2), while the second factor is Na-metabisulfite concentration (S): $250 \mathrm{ppm}$ (S1), $500 \mathrm{ppm}$ (S2), and $750 \mathrm{ppm}$ (S3). The results showed that the good quality of carrot flour was obtained from the combination treatment of the Tosari variety with a concentration of $500 \mathrm{ppm}$ Na-metabisulfite. The resulting carrot flour has a decrease in total carotene by $5,46 \%$; water content $2,84 \%$; $\mathrm{Aw} 0,36$; yield $6,56 \% ; \mathrm{SO}_{2}$ residue $54,4 \mathrm{ppm}$; color and odor preferences of 8,07 and 5,87 .
\end{abstract}

Kata Kunci : Carrot powder, arnas, tosari, carotene total

http://ejournal.urindo.ac.id/index.php/pertanian

Article History :

Sumbitted 11 Juni 2021, Accepted 30 Juni2021, Published 30 Juni2021 


\section{Jurnal IImiah Respati}

\section{PENDAHULUAN}

Kekurangan vitamin A hingga kini masih saja merupakan penyebab utama kebutaan, terutama anak- anak di bawah umur 5 tahun. Biasanya terjadi sejak bayi berusia 6 bulan, karena produksi ASI telah menurun sehingga kebutuhan vitamin A tidak tercukupi. Menurut WHO, untuk bayi yang berusia 6 bulan sampai 12 bulan diperlukan setiap harinya 1,800 $\mu \mathrm{g}$ karoten (3,000 SI vitamin A) [14].

Vitamin A tidak terdapat pada jaringan tanaman, tetapi terdapat sebagai pro vitamin A yang disebut karoten. Karoten terdapat terutama dalam sayur-sayuran dan buah-buahan segar dan terutama yang berwarna kuning misalnya tomat, wortel, bijibijian seperti jagung kuning dan sebagainya [9]. Wortel merupakan sumber pro vitamin A yang terbaik dibandingkan dengan sayuran lain. Kandungan pro vitamin A dalam wortel kurang lebih 10 kali buah tomat [12].

$$
\text { Kandungan karoten yang }
$$

tinggi pada wortel, menuntut adanya penanganan pasca panen yang seksama, karena wortel merupakan komoditi sayuran yang memiliki sifat mudah rusak. Hal ini disebabkan kadar air wortel cukup tinggi sekitar 88\% [1]. Salah satu tindakan penanganan wortel adalah dengan cara pengeringan dan diolah dalam bentuk tepung. Keuntungan bahan kering adalah berat bahan menjadi lebih ringan, dan volumenya menjadi lebih kecil, sehingga mempermudah pengangkutannya, di samping itu bahan menjadlebih awet [11].

Produk wortel kering dapat digunakan untuk sop kering, campuran saos, sop yang dikalengkan, makanan bayi, dan sebagai bahan pewarna alami (coloring agent) untuk produk makanan khusus seperti keju, minuman dari jeruk, produk roti, ice cream, an pembuatan minyak [4]. Kadar zat gizi dan mutu [8] wortel dipengaruhi oleh banyak faktor seperti varietas, tempat tumbuh, tingkat kemasakan, suhu, kadar air dan lain-lain. Umbi wortel yang telah tua terasa keras dan pahit. Senyawa yang menyebabkan pahit disebut isokumarin. Oleh karena itu waktu pemanenan dilakukan pada saat masih muda.

Pertumbuhan wortel untuk pengeringan [10] adalah lebih besar, lebih matang, dan lebih tinggi karoten dan padatannya daripada wortel yang di pasarkan dalam bentuk segar. Kandungan vitamin A dalam bentuk kering mengalami peningkatan sebesar 2,37\% dibandingan bentuk segar [13]. Pada pembuatan tepung wortel, sering terjadi penurunan kandungan karoten 


\section{Jurnal IImiah Respati}

yang terlalu tinggi. Usaha-usaha untuk mengurangi kehilangan karoten adalah dengan melakukan blanching dan penambahan sulfit atau $\mathrm{SO}_{2}$ sebelum proses pengeringan.

\section{METODE}

Penelitian ini dilaksanakan di Laboratorium Sentral IImu dan Teknologi Pangan, Laboratorium Pilot Plant dan Laboratorium Processing Mekanisasi Fakultas Pertanian Universitas Brawijaya Malang. Bahan untuk kegiatan penelitian ini adalah wortel varietas Arnas dan Tosari, Natrium sulfat, $\mathrm{NaOH} 5 \mathrm{~N}$, lodin $0,02 \mathrm{~N}, \mathrm{HCl}$ $5 \mathrm{~N}$, Amilum $1 \%$, formaldehid 36-40\%, petroleum eter, aquadest, dan Nametabisulfit.

Alat yang di gunakan untuk penelitian ini adalah oven, cuvet, spektrofotometer, tabung reaksi, beaker glass, pipet ukur, thermometer, corong pemisah, timbangan,

\section{HASIL DAN PEMBAHASAN}

\section{Kadar Air (\%)}

Hasil analisis penentuan kadar air tepung wortel berkisar antara 2,70 - 2,97\%. Hasil tersebut memenuhi apa yang dinyatakan Desrosier (1988), bahwa produk sayuran berbentuk bubuk/tepung mempunyai kadar pisau stainless stell, mixer magnetic, pipet tetes, buret, Aw-meter, erlenmeyer, botol timbang, kertas saring dan kertas Whatman 4.2.

Metode penelitian ini menggunakan Rancangan Acak Kelompok (RAK) secara faktorial yang terdiri dari 2 faktor dengan 3 ulangan, Faktor 1 adalah varietas wortel (W), yang terdiri dari 2 taraf yaitu : varietas Arnas (W1) dan varietas Tosari (W2). Faktor 2, terdiri 3 taraf, yaitu : Konsentrasi $\mathrm{Na}-$ metabisulfit (S) : 250 ppm (S1), 500 ppm (S2), dan 750 ppm (S3).

Parameter penelitian meliputi kadar air, Aw, residu $\mathrm{SO}_{2}$, total karoten, rendemen, uji organoleptik terhadap bau dan warna. Analisis data menggunakan analisis sidik ragam uji " $F$ " (Analisis of variens), pada tingkat signifikan $1 \%$. Apabila terdapat perbedaan di antara perlakuan dilanjutkan dengan uji BNT $1 \%$ dan uji JNT $1 \%$.

air 2 - 3\%. Waktu yang dibutuhkan untuk mencapai kadar air tersebut adalah $11-12$ jam. Berdasarkan analisis sidik ragam, menunjukkan bahwa perlakuan varietas wortel berpengaruh sangat nyata, sedangkan konsentrasi Na-metabisulfit dan interaksinya tidak menunjukkan pengaruh yang nyata terhadap kadar air tepung wortel.

Tabel 1. Pengaruh varietas wortel terhadap kadar air tepung wortel

\begin{tabular}{lccc}
\hline Varietas Wortel & $\begin{array}{c}\text { Rata-rata } \\
\text { Kadar air (\%) }\end{array}$ & Notasi * & BNT 1\% \\
\hline Tosari & 2,77 & a & 0.093 \\
Arnas & 2,98 & b & \\
\hline
\end{tabular}




\section{Jurnal IImiah Respati}

Keterangan: Harga rata-rata kadar air dengan notasi berbeda berarti terdapat perbedaan yang sangat nyata, pada taraf nyata $1 \%$.

Perbedaan kadar air tepung wortel yang dihasilkan dari ke dua varietas sesuai dengan penelitian bahwa kadar air wortel dipengaruhi oleh varietas, tingkat kemasakan, dan tempat tumbuhnya. Faktor-faktor utama yang mempengaruhi kecepatan pengeringan dari suatu mutu bahan pangan [2], di antaranya adalah sifat fisik dan kimia dari produk (bentuk, ukuran, komposisi kadar air). Tepung wortel yang dihasilkan dari varietas Arnas lebih tinggi dibanding dari varietas Tosari, hal ini disebabkan kadar air awal varietas Arnas lebih tinngi dan juga total padatan terlarutnya. Selama proses pengeringan, air yang terdapat dalam wortwl varietas Arnas sulit diuapkan karena terikat oleh molekul-molekul gula melalui ikatan hidrogen, sehingga waktu pengeringan yang sama kadar airnya lebih besar disbanding varietas Tosari.

\section{Aktivitas Air (Aw)}

Penyebab utama kerusakan bahan pangan adalah pertumbuhan mikroorganisme, kegiatan enzim, dan perubahan kimia. Pertumbuhan mikroorganisme merupakan penyebab utama penyusutan bahan pangan.
Kegiatan ini berlangsung paling cepat pada aktivitas iar yang tinggi, didukung oleh faktor suhu, $\mathrm{pH}$, dan faktor lingkungan lainnya.

Aktivitas air (water activity) merupakan jumlah air bebas yang dapat dipergunakan oleh mikroorganisme untuk pertumbuhannya. Berbagai mikroorganisme mempunyai aktivitas air (Aw) minimum agar tumbuh dengan baik, misalnya khamir $(0,80-0,90)$, kapang $(0,6-$ $0,7)$ dan bakteri $(0,90)$ [14]. Besarnya Aw bahan berkurang setelah pengeringan. Hal ini disebabkan air bebas, yaitu air yang secara fisik terikat dalam jaringan matriks bahan seperti serat, kapiler, dan lain-lain akan terlepas dan menguap selama pengeringan.

Berdasarkan analisis sidik ragam, menunjukkan bahwa perlakuan varietas wortel berpengaruh sangat nyata terhadap Aw tepung wortel, sedangkan konsentrasi $\mathrm{Na}$ metabisulfit dan interaksi antara ke 2 perlakuan tidak menunjukkan pengaruh yang nyata terhadap Aw tepung wortel. Dari Tabel 2. terlhat nilai rata-rata Aw tepung wortel berkisar $0,27-0,36$, dengan demikian terhindar dari bakteri, khamir dan kapang.

Tabel 2. Pengaruh varietas wortel terhadap aw tepung wortel

\begin{tabular}{lccc} 
Varietas Wortel & Rata-rata Aw & Notasi & BNT 1\% \\
\hline Tosari & 0,27 & a & 0.009 \\
Arnas & 0,36 & b & \\
\hline
\end{tabular}

Keterangan: Harga rata-rata Aw dengan notasi berbeda berarti terdapat perbedaan yang sangat nyata, pada taraf nyata $1 \%$. 
Adanya kenaikan jumlah air yang terikat oleh zat terlarut seperti gula dan garam akan menurunkan jumlah air bebas [6]. Total padatan terlarut menunjukkan jumlah zat terlarut yang terdapat dalam bahan, selama pematangan akan terjadi kenaikan jumlah zat terlarut yang disebabkan karena terjadinya berbagai peristiwa pemecahan senyawasenyawa kompleks yang tidak larut menjadi senyawa-senyawa yang larut. Perombakan zat pati menjadi sukrosa dan selanjutnya diubah menjadi gula-gula reduksi yang larut serta terjadinya perombakan protopektin menjadi asam pektat yang dapat larut. Dua peristiwa inilah yang menyebabkan peningkatan jumlah padatan terlarut dalam bahan. Varietas Arnas mempunyai total padatan terlarut yang lebih tinggi $\left(1,35^{\circ}\right.$ Brix) dibanding varietas Tosari $\left(1,34^{\circ}\right.$ Brix $)$ sehingga air yang terikat lebih besar disbanding air bebasnya, dan nilai Awnya kecil setelah pengeringan.

\section{Residu $\mathrm{SO}_{2}$ (ppm)}

Nilai rata-rata residu $\mathrm{SO}_{2}$ pada produk akhir, yaitu antara $43,73-76,87$. Residu $\mathrm{SO}_{2}$ tersebut masih berada dalam batas yang diijinkan, yaitu tidak lebih dari 500 ppm. Adanya $\mathrm{SO}_{2}$ dalam bahan makanan dengan dosis yang tinggi, selain merusak kandungan vitamin bahan seperti vitamin B1 juga menyebabkan sakit perut (pada bayi), mengganggu mata dan sistem pernafasan. Berdasarkan analisis sidik ragam, menunjukkan bahwa interaksi antara perlakuan varietas wortel dan konsentrasi $\mathrm{Na}$ metabisulfit menunjukkan pengaruh sangat nyata terhadap residu $\mathrm{SO}_{2}$ tepung wortel.

Tabel 3. Pengaruh varietas wortel dan konsentrasi Na-metabisulfit terhadap residu $\mathrm{SO}_{2}$ tepung wortel

\begin{tabular}{lccc}
\hline Perlakuan & $\begin{array}{c}\text { Rata-rata } \\
\text { Residu } \mathrm{SO}_{2}(\mathrm{ppm})\end{array}$ & Notasi & JNT 1\% \\
\hline W2S1 & 43,733 & $\mathrm{a}$ & \\
W1S1 & 52,287 & $\mathrm{~b}$ & 3,942 \\
W2S2 & 54,400 & $\mathrm{~b}$ & 4,129 \\
W2S3 & 64,000 & $\mathrm{c}$ & 4,217 \\
W1S2 & 70,400 & $\mathrm{~d}$ & 4,292 \\
W1S3 & 76,867 & $\mathrm{e}$ & 4,329 \\
\hline
\end{tabular}

Keterangan: Harga rata-rata residu $\mathrm{SO}_{2}$ dengan notasi berbeda berarti terdapat perbedaan yang sangat nyata pada taraf nyata $1 \%$.

Melalui uji JNT 1 \% (Tabel 3), terlihat masingmasing kombinasi perlakukan menunjukkan perbedaan yang nyata, sedangkan kombinasi perlakuan varietas Tosari dan konsentrasi $\mathrm{Na}$ metabisulfit 500 ppm tidak berbeda dengan kombinasi perlakuan varietas Arnas dan konsentrasi Na-metabisulfit 250 ppm. Pemberian Na-metabisulfit dengan konsentrasi yang semakin tinggi, meningkatkan residu $\mathrm{SO}_{2}$ tepung wortel. $\mathrm{Hal}$ 
ini disebabkan semakin besar konsentrasi Nametabisulfit yang diberikan, maka $\mathrm{SO}_{2}$ yang diserap oleh bahan semakin besar, sehingga residu $\mathrm{SO}_{2}$ yang dihasilkan besar.

Residu $\mathrm{SO}_{2}$ tepung wortel tertinggi dihasilkan dari kombinasi perlakuan varietas Arnas dan konsentrasi Na-metabisulfit 750 ppm (75,67 ppm), sedangkan terendah dihasilkan dari kombinasi perlakuan varietas Tosari dan konsentrasi Na-metabisulfit 250 ppm (43,73 ppm).

Jumlah penyerapan dan penyimpanan $\mathrm{SO}_{2}$ dalam bahan makanan yang dikeringkan dipengaruhi oleh varietas, kemasakan, ukuran bahan, konsentrasi $\mathrm{SO}_{2}$ yang digunakan dan lain-lain [11].

Tekstur suatu bahan berbeda untuk berbagai varietas. Secara kimiawi perubahan tekstur disebabkan karena adanya perubahan yang terjadi pada dinding sel dan substansi pektin yang lain. Hal ini ditandai dengan terjadinya depolimerisasi pektin yang tidak larut menjadi pektin yang larut sehingga meningkatkan kandungan total padatan terlarut dan menyebabkan pelunakan. Varietas Arnas mempunyai tekstur yang lebih lunak $\left(3,1 \times 10^{-}\right.$ ${ }^{4} \mathrm{~mm} / \mathrm{g} /$ det) dibanding varietas Tosari yang mempunyai tekstur keras $\left(1,0 \times 10^{-4}\right.$ $\mathrm{mm} / \mathrm{g} /$ det), sehingga jumlah $\mathrm{SO}_{2}$ yang diserap yang tersimpan lebih besar dibanding varietas Tosari.

\section{Rendemen (\%)}

Rendemen merupakan berat akhir bahan setelah pengeringan dengan berat bahan dasar, yang dinyatakan dalam persen. Nilai rata-rata rendemen tepung wortel yang dihasilkan antara 6,44 - 7,33\%. Kadar bahan kering berkisar antara 7,2 - 13,3\% (dari berat segar) [8]. Berdasarkan analisis sidik ragam, menunjukkan bahwa perlakuan varietas wortel, konsentrasi Na-metabisulfit dan interaksi kombinasi ke 2 perlakuan tidak menunjukkan pengaruh sangat nyata terhadap rendemen tepung wortel. Kombinasi perlakuan varietas Tosari dan konsentrasi $\mathrm{Na}$ metabisulfit 750 ppm, menghasilkan rendemen terbesar (7,37\%) walaupun tidak berbeda dengan yang lain. Perbedaan varietas menyebabkan perbedaan konsentrasi zat padatan terlarut dan zat padat total. Varietas Tosari mempunyai kadar air yang lebih kecil $(88,21 \%)$ dibanding varietas Arnas $(89,97 \%)$, sehingga total padatannya besar. Total padatan suatu bahan akan mempengaruhi berat setelah pengeringan, dimana semakin besar total padatannya, berat akhir menjadi semakin besar.

\section{Penurunan Total Karoten (\%)}

Nilai rata-rata penurunan total karoten berkisar 5,46 - 19,88\%. Penurunan total karoten tersebut tidak jauh berbeda [3], yaitu suatu metode pengeringan komersial yang baik akan menyebabkan penurunan karoten sebesar $5 \%$. Berdasarkan analisis sidik ragam, menunjukkan bahwa perlakuan varietas wortel, konsentrasi Na-metabisulfit dan interaksi kombinasi ke 2 perlakuan 
menunjukkan pengaruh sangat nyata terhadap

penurunan total karoten tepung wortel.

Tabel 4. Pengaruh varietas wortel dan konsentrasi Na-metabisulfit terhadap penurunan total karoten tepung wortel

\begin{tabular}{cccc}
\hline Perlakuan & Rata-rata & Notasi * & JNT1 \% \\
& Penurunan Total Karoten (\%) & & \\
\hline W2S2 & 5,459 & $\mathrm{a}$ & \\
W1S1 & 6,307 & $\mathrm{a}$ & 2,695 \\
W2S1 & 7,511 & $\mathrm{a}$ & 2,823 \\
W1S2 & 17,323 & $\mathrm{~b}$ & 2,883 \\
W1S3 & 18,009 & $\mathrm{~b}$ & 2,935 \\
W2S3 & 19,883 & $\mathrm{~b}$ & 2,960 \\
\hline
\end{tabular}

Keterangan: Harga rata-rata penurunan total karoten dengan notasi berbeda berarti terdapat perbedaan yang sangat nyata pada taraf nyata $1 \%$.

Pada Tabel 4. terlihat kombinasi varietas Tosari dan konsentrasi Na-metabisulfit 750 ppm penurunan total karoten terbesar (19,883\%), dan terkecil pada kombinasi varietas Tosari dan konsentrasi Nametabisulfit 500 ppm (5,459\%). Kerusakan pigmen karoten disebabkan karena oksidasi enzimatis, oksidasi non enzimatis dan isomerisasi. Selanjutnya dikatakan pigmen karoten cenderung menunjukkan stabilitas yang rendah dalam pengeringan dengan suhu tinggi, tetapi tetap stabil di bawah kondisi proses seperti pembekuan dan di dalam panas sterilisasi. Selain itu dalam kondisi sama akan mengalami kerusakan, namun tetap stabil pada kondisi basa [5].

Pemberian Na-metabisulfit 750 ppm pada varietas Tosari, menyebabkan kondisi bahan menjadi lebih asam karena adanya penambahan ion hydrogen $\left(\mathrm{H}^{+}\right)$. Kondisi asam menyebabkan penurunan total karoten lebih besar, dimana karoten mengalami isomerisasi dari bentuk trans ke cis menyebabkan serapan warna maksimum dari karoten terletak pada panjang gelombang yang lebih pendek dan warna karoten menjadi lebih pucat. Bentuk trans [4] merupakan bentuk paling stabil disbanding bentuk cis.

Pemberian Na-metabisulfit 500 ppm pada varietas Tosari, efek penghambatan kerusakan karoten mencapai derajat optimal dibanding pada konsentrasi 250 ppm. Hal ini disebabkan varietas Tosari mempunyai tekstur yang keras, sehingga memerlukan konsentrasi Na-metabisulfit yang lebih besar untuk menghambat kerusakan karoten. Selanjutnya seperti pada varietas Arnas, semakin besar konsentrasi Na-metabisulfit menyebabkan penurunan total karoten lebih besar.

\section{Uji organoleptik}

Pengujian seaca organoleptik terhadap produk tepung wortel dilakukan dengan metode hedonic scale scoring yang meliputi bau dan warna. Skor berkisar antara $1-9$, 
dimana 1 berarti amat sangat tidak menyukai dan 9 berarti amat sangat menyukai.

\section{Uji Warna}

Salah satu faktor yang sangat mempengaruhi mutu bahan makanan adalah warna. Hal ini bukan berarti faktor-faktor yang lain diabaikan, akan tetapi sebelum faktorfaktor lain dipertimbangkan, secara visual faktor warna tampil lebih dahulu dan kadangkadang sangat menentukan. Nilai rata-rata

Tabel 5. Pengaruh varietas wortel dan konsentrasi Na-metabisulfit terhadap tingkat kesukaan warna tepung wortel

\begin{tabular}{lccc}
\hline Perlakuan & $\begin{array}{c}\text { Rata-rata } \\
\text { Tingkat Kesukaan Warna }\end{array}$ & Notasi * & JNT 1\% \\
\hline W2S3 & 3,00 & a & \\
W2S1 & 5,00 & b & 1,371 \\
W1S3 & 5,13 & b & 1,411 \\
W1S2 & 5,33 & b & 1,452 \\
W2S2 & 6,07 & b & 1,484 \\
W1S1 & 6,80 & c & 1,502 \\
\hline
\end{tabular}

Keterangan: Harga rata-rata Tingkat kesukaan warna dengan notasi berbeda berarti terdapat perbedaan yang sangat nyata pada taraf nyata $1 \%$.

Tingkat kesukaan warna tertinggi dihasilkan pada perlakuan varietas Arnas dengan konsentrasi Na-metabisulfit 250 ppm $(6,8)$, sedangkan tingkat kesukaan terendah dihasilkan pada perlakuan varietas Tosari dengan konsentrasi Na-metabisulfit 750 ppm $(3,00)$. Hal ini disebabkan penurunan total karoten pada kombinasi perlakuan varietas Arnas dan konsentrasi Na-metabisulfit 250 ppm lebih rendah $(6,31 \%)$ dibanding dengan kombinasi varietas Tosari dengan konsentrasi Na-metabisulfit 750 ppm (19,88\%). Melalui uji JNT $5 \%$, terlihat bahwa kombinasi perlakuan varietas Tosari dan konsentrasi Na- tingkat kesukaan warna berkisar antara 3,0 6,8 , yaitu antara tidak menyukau sampai menyukai. Berdasarkan analisis sidik ragam, menunjukkan bahwa perlakuan varietas wortel menunjukkan pengaruh yang nyata, konsentrasi Na-metabisulfit dan interaksi antara ke 2 perlakuan menunjukkan pengaruh sangat nyata terhadap tingkat kesukaan warna tepung wortel. 
Jurnal IImiah Respati

antara kedua perlakuan menunjukkan kesukaan bau tepung wortel.

pengaruh yang nyata terhadap tingkat

Tabel 6. Pengaruh varietas wortel dan konsentrasi Na-metabisulfit terhadap tingkat kesukaan bau tepung wortel

\begin{tabular}{lcll}
\hline Perlakuan & $\begin{array}{c}\text { Rata-rata } \\
\text { Tingkat Kesukaan Bau }\end{array}$ & Notasi & JNT 1 \% \\
\hline W2S3 & 4,27 & a & \\
W1S3 & 4,97 & a & 1,013 \\
W1S2 & 5,00 & a & 1,067 \\
W1S1 & 5,20 & a & 1,103 \\
W2S2 & 5,87 & b & 1,125 \\
W2S1 & 6,87 & b & 1,147 \\
\hline
\end{tabular}

Keterangan: harga rata-rata tingkat kesukaan bau dengan notasi berbeda berarti terdapat perbedaan yang sangat nyata pada taraf nyata $1 \%$.

Dari uji JNT $5 \%$ pada Tabel 6 tampak bahwa kombinasi perlakuan varietas Tosari dan konsentrasi Na-metabisulfit 250 ppm dan 500 ppm menunjukkan perbedaan yang nyata dibanding kombinasi perlakuan lainnya. Bau wortel disebabkan adanya minyak atsiri yang disebut carrot seed oil. Carrot seed oil tersebut dapat menguap selama pengolahan [7].

Kombinasi perlakuan varietas Tosari dan konsentrasi Na-metabisulfit 250 ppm menghasilkan tingkat kesukaan bau tepung wortel tertinggi $(6,87)$, sedangkan varietas Tosari dan konsentrasi Na-metabisulfit 750 ppm menghasilkan tingkat kesukaan bau yang terendah $(4,27)$. Hal ini disebabkan penurunan total karoten pada kombinasi varietas Tosari dan konsentrasi Nametabisulfit 750 ppm sangat besar.

Kerusakan karoten [5] sebagai akibat oksidasi enzimatis, akan menghasilkan epoksida atau furanoksida. Di samping itu lemak juga akan teroksidasi membentuk hidroperoksida dan komponen karbonil dengan bau tidak sedap dan senyawa yang mudah menguap. Adanya bau yang tidak sedap menyebabkan panelis kurang menyukai tepung wortel yang dihasilkan.

\section{KESIMPULAN}

Pengaruh Na-metabisulfit setelah blanching meningkatkan residu $\mathrm{SO}_{2}$, tingkat kesukaan terhadap warna, bau dan memperkecil penurunan total karoten tepung wortel. Ditinjau dari pengaruh utama varietas wortel, varietas Tosari mempunyai kadar air, residu $\mathrm{SO}_{2}$ dan penurunan total karoten yang rendah, sedangkan $\mathrm{Aw}$, rendemen lebih tinggi dibanding varietas Arnas. Interaksi antara varietas wortel dan konsentrasi $\mathrm{Na}$ metabisulfit memperkecil penurunan total karoten, meningkatkan residu SO2 dan tingkat kesukaan terhadap warna dan bau tepung wortel. Secara keseluruhan perlakuan yang memberikan mutu tepung wortel yang 
baik diperoleh dari kombinasi perlakuan varietas Tosari dengan konsentrasi Na-metabisulfit 500 ppm. Tepung wortel yang dihasilkan mempunyai penurunan total karoten sebesar 5,46\%, kadar air 2,84\%, Aw 0,36 , rendemen $6,56 \%$, residu $\mathrm{SO}_{2} 54,4$ ppm, tingkat kesukaan warna dan bau sebesar 8,07 dan 5,87

\section{DAFTAR PUSTAKA}

Anonymous, 1981. Daftar Komposisi Bahan Makanan. Bhatara Karya Aksara Jakarta.

Buckle, K.A., R.A. Edwards, G.H. Fleet, dan M. Wootton, 1987. Ilmu Pangan. UI-Press. Jakarta

Desrosier, N. W. (1988). Teknologi Pengawetan Pangan (Terjemahan). Universitas Indonesia Press. Jakarta.

De Man, J.M., 1976. Principles of Food Chemistry. The AVI Publishing Company Inc. Westport Connecticut.

Eskin, N.A.M., H.M. Hendersen, dan R.J. Towsend, 1971. Biochemistry of Food. Academic Press New York.

Gunarif, T.S. Gumbira, dan W.Sutedja, 1987. Operasi Pengeringan pada Pengolahan Hasil Pertanian. PT. Melton Putra Jakarta.

Harris, R., 1987. Tanaman Minyak Atsiri. Penerbit Swadaya Jakarta
Harris, R. S. dan E. Karmas. 1989.

Evaluasi Gizi pada Pengolahan

Bahan Pangan. Penerjemah: S.

Achmadi. ITB - Press, Bandung

Lestariana, W, dan M. Madiyah, 1988.

Analisa Vitamin dan Elektrolit

Organik. UGM Yogyakarta

Luh, B dan J.G. Woodroof, 1975.

Commercial Vegetable Processing.

The AVI Publishing Company Inc.

Mucthtadi, D; T. R. Muchtadi dan E. Gumbira. (1979). Pengolahan Hasil Pertanian II Nabati. FatemetaInstitut Pertanian Bogor. Bogor.

Tranggono, Zuheid N., dan Joko Wibowo, 1988. Evaluasi Pengolahan Pangan dan Gizi. UGM Yogyakarta

Watt, B.K., dan Merrill A.L., 1975. Consumer and Food Economic. Institute Agricultural Research Service United State Department of Agriculture New York.

Winarno, F.G., 1982. Kimia Pangan dan Gizi. PT. Gramedia Jakarta , 1985. Gizi dan Makanan

Bagi Bayi dan Anak Sapihan PT. Sinar Harapan Jakarta. 